\title{
TRACKING LIABILITY - TRACEABILITY AND THE FARMER
}

\section{PATRICIA FARNESE}

Many farmers are reluctant to enter into traceability programs, which would create a record of the source and movemen of ran' farm products. Farmers are concerned that these programs could make them more vulnerable to regulatory offence prosecution and negligence lawsuits, as the protection afforded by anonymity is lost. However, participating in a traceability program may assist a farmer in establishing due diligence and reasonable care. Canadianjurisprudence also suggests that it will likely be difficull to overcome the causation stage of a negligence claim and ulimately prove a farmer's liability. Morcover, farmers will also benefi from the restrictive treatment of pure economic loss claims by Canadian courts. Traceability programs would therefore prove ta be more positive than negative for Canadian farmers.
Un grand nombre d'agriculteurs hésitent à participer d̀ des programmes de traçabilité qui créeraten un dossier sur la source et le mouvement des produits agricoles à l'élat brut. Les agriculleurs $s$ inquiètent que ces programmes les rendraient plus vulnirables aux poursuites pour infractions réglementaires et négligence, étant domé que la protection assurée par l'anonymat n'existerait plus. Cependant. le fait de participer à un tel programme pourrait aider l'agriculteur à établir diligence raisonnable et soins raisonnables. La jurisprudence canadienne indigue aussi qu 'il serait probablement difficile de surmonter l'élape de la causalicé d'une poursuite pour négligence el, en définitive, pronver la responsabilite de lagriculieur. De plus. les agriculteurs profiteront aussi du traitement restrictif des poursuites pour pertes iconomiques par les tribumanx canadiens. Les programmes de traçabilite présenteraient alors plus d'avantages que $d$ 'inconvinients pour les agriculteurs canadiens.

\section{TABLE OF CONTENTS}

I. INTRODUCTION ................................ 203

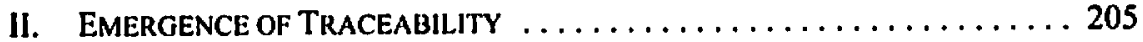

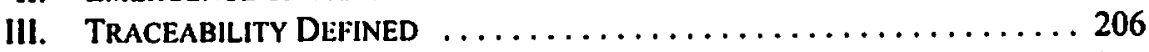

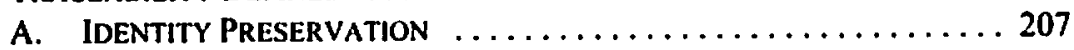

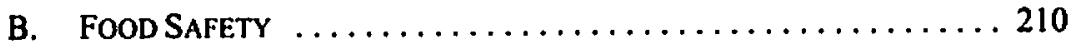

C. Operation of Traceability Programs $\ldots \ldots \ldots \ldots \ldots \ldots 211$

IV. TRACEABILITY AND ON-FARM LIABILITY $\ldots \ldots \ldots \ldots \ldots \ldots \ldots 212$

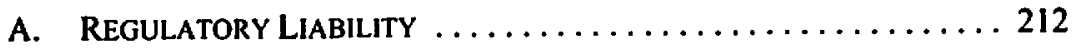

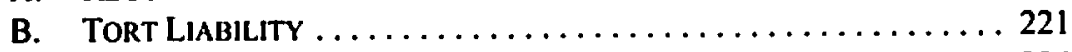

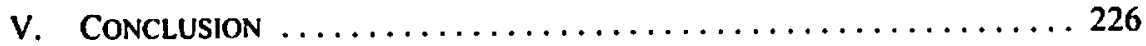

\section{INTRODUCTION}

Global concerns over terrorism, allergens, disease, chemical residues, and genetic engineering have intensified public concerns over food safety in recent years. Crises involving Avian Influenza and Bovine Spongiform Encephalopathy (BSE) have focused

- Assistant Prolessor, College of Law and Senior Law Fellow at the Centre for Studies in Agriculture, Law and the Environment at the University of Saskatchewan. Research for this article was supported with funds provided by the Private Sector Risk Management Partnership of Agriculture and Agri-food Canada. 
attention onto farm production practices which affect the health and quality of food.' As a result, farmers are increasingly being asked by government, customers, and industry associations to participate in on-farm programs, called traceability programs, in response to the public's heightened interest in food safety and environmental protection. These traceability programs track the movement of raw farm products from the farm to the retail consumer's purchase. Canada's Agricultural Policy Framework, ${ }^{2}$ the first comprehensive national farm policy in Canada, specifically identifies traceability as one of the key components of its food safety strategy, and establishes ambitious goals in respect to farmer participation in traceability initiatives.

While traceability may safeguard consumer confidence and help protect market access, the potential exists for traceability to increase liability for farmers. For the majority of farmers who are not involved in the direct marketing of their products, traceability removes anonymity in the value-added chain between the farm and the retail consumer. Without traceability, a farmer's products become commingled with other farmers' products after they leave the farm gate, thereby becoming indistinguishable from other products. Traceability increases the likelihood that a single farmer will be identified as the source of an environmental or food safety problem. Accordingly, many producers may ultimately choose not to participate in traceability initiatives due to a fear of increased risk of liability. Farmers who decide to participate in traceability initiatives will need to consider the requirements of due diligence and reasonable care when making production decisions if they wish to avoid regulatory and civil liability.

Much has been written about the content of due diligence in environmental offences. ${ }^{3}$ The same analysis has not yet been undertaken in relation to food and agricultural regulation. This paper explores the relationship between traceability and due diligence in the regulation of food and agriculture. Existing case law with respect to consumer protection offences in the agriculture and food sectors suggests that the risk of liability for farmers remains relatively low. Participation in an on-farm traceability program will arguably increase the likelihood that a farmer will face regulatory prosecutions as well as civil lawsuits initiated by consumers. At the same time however, Canadian jurisprudence with respect to consumer protection offences and negligence claims in the agriculture and food sector indicates that

I In 2003, the first animal with BSE was found in Canada following the confirmed link between the death of a number of people in the UK and the consumption of beef from cattle with BSE. On 2 May 2007. the Canadian Food Inspection Agency (CFIA) initiated its tenth investigation of animals with BSE. See CFIA, "Bovine Spongiform Encephalopathy (BSE) in North America" ( 4 September 2007), online: CFIA <http://www.inspection.gc.ca/english/anima/heasan/disemala/bsecsb/bseesbindexe.shtml>. Likewise, in 2004, a strain of the Avian Influenza virus infected a number of birds in Canada following a number of human deaths from a different strain of Avian Influenza in Asia. See CFIA, "Avian Influenza" (28 September 2007), online: CFIA <http:/www.inspection.gc.ca/english/anima/heasan/ disemala/avflu/avflue.shtml>.

: Agriculture and Agri-Food Canada, Federal-Provincial-Terrilorial Agreement on Agricultural and AgriFood Policy for the Twenty-Finst Cennery, online: Agriculture and Agri-Food Canada $<$ <http://www.agr.gc.ca/progser/index_e.phtml> (commonly called Agricultural Policy Framework) $[A P F]$.

See e.g. Scott R. Miller \& Kevin S. MacFarlane, "Environmental Risk Allocation in the Asset Rationalization Process" (1992) 30 Alta. L. Rev. 94; N.J. Strantz, "Beyond R. v. Sault Ste. Marie: The Creation and Expansion of Strict Liability and the Duc Diligence Defence" (1992) 30 Alta. L. Rev. 1233. 
an on-farm traceability program may ultimately assist the farmer in establishing that the farmer has acted with due diligence and reasonable care.

\section{EMERgence Of TraceabiLity}

In the past, most food did not travel great distances to reach the consumer. If a food safety concern arose, it was relatively easy to identify the source and contain the problem. In today's market where few products are locally consumed, there is a high probability that an isolated food safety problem on a farm will be imported to another locale before it can be contained. For example, in 2006, bagged fresh spinach produced in the United States was the subject of global recalls after spinach from Califomia was found to be contaminated with $E$. coli bacteria. It is suspected that wild pigs on one or two farms in Califomia were responsible for the contamination of the spinach. As a result of the contamination, a number of people throughout the U.S. became ill resulting in three reported deaths. Furthermore, it has been reported that at least one person in Canada became ill after eating the contaminated spinach."

The Canadian government responded swiftly to the $E$. coli contamination of American spinach by banning all imports of fresh spinach from the U.S. including bagged salad mixes containing spinach. ${ }^{6}$ The Canadian government banned all American spinach despite it being clearly known that only one company's products were implicated in the outbreak. ${ }^{7}$ The complete ban remained in place for almost two months when it was downgraded to a ban on spinach originating from the San Benito and Monterey counties of California. ${ }^{8}$

With perishable commodities, even a temporary denial of access to markets can have devastating consequences for farmers. The global nature of agricultural markets also means that even an isolated food safety problem can have a significant impact on farms throughout the implicated sector. Furthermore, once restrictions are lifted, consumers may still lack confidence in the safety of the product, thereby extending the impact of the food safety incident. American spinach producers witnessed the effect of a food safety crisis when a planned public relations "spinach-eating" news conference organized by a U.S. congressman to restore consumer confidence in spinach was thwarted after spinach could not be located." Indeed, supermarkets continued to refuse to stock spinach products even after the American ban on the products had been lifted. ${ }^{10}$

"3rd Death Linked to Tainted Spinach in the US" CBC News (7 October 2006), online: CBC News <www.cbc.ca/consumer/story/2006/10/07/spinach.html>.

lbid.

CFIA, News Release, "Health Hazard Alen: Various Brands of Imponted Fresh Spinach May Contain E.coli 0157:H7 Bacteria" (15 September 2006), online: CF1A <htip://www.inspection.gc.ca/english/ corpaffr/recurapp/2006/20060915be.shtml>.

Ibid.

- CFIA, News Release, "Canada eases border restrictions on fresh spinach from the United States" (30 October 2006), online: CFIA <http://www.inspection.ge.ca/english/plaveg/fresh/salsal/spinepin/usa spine.shtml>.

- "Yes, We Have No Spinach" Food Chemical News 48:35 (9 October 2006) 3.

10 Ibid. 
As a result of food safety crises, there is increased attention devoted to agricultural practices. It should be noted, however, that it is not just food safety concerns that have increased public interest in agricultural production practices. The agriculture industry's role in the Walkerton and North Battleford water contamination crises had many people question on-farm management practices. " Likewise, concerns with respect to the impact of chemical residues and genetically modified organisms on consumer health and the treatment of agricultural labourers have focused public attention on agricultural practices. ${ }^{12}$ Agriculture's impact on the environment, including water quality, air-borne pollutants, energy consumption and human welfare have increased demands that the Canadian government require farmers to monitor and account for the environmental impact of their farm practices. Taken logether, these various concerns surrounding food safety and agricultural practices have resulted in a growing call for traceability programs.

The Canadian government has always intervened to some extent in the production and distribution of food to ensure an acceptable level of quality and safety. ${ }^{13}$ Currently, the production and supply of food attracts a great deal of regulations. ${ }^{14}$ In fact, it is difficult to identify another regulatory framework that is as extensive as that involving food. Food is regulated at the local, provincial, federal, and international levels, creating a complex and overlapping regulatory framework. The introduction of traceability in Canadian agricultural policy is a continuation of government regulation of food production.

\section{TRACEABILITY DEFINED}

In order to assess the on-farm implications of participation in traceability programs, it is necessary to understand what traceability is and what it seeks to achieve. The $A P F$ expressly defines traceability as "the ability to trace the history, application or location of an entity by means of recorded identifications."15 Traceability programs in the food sector can be described as initiatives to track the movement of raw farm products from the farm through handling by processors, distributors, transporters, and retailers, to the delivery of the final product to the retail consumer. Traceability programs may also track suppliers of inputs such

Ontario, Ministry of the Attorncy General, Report of the Walkerton Inyuiry, vol. I (Toronto: Ministry of the Attomey General, 2002) (Chair: Dennis R. O'Connor); Saskatchewan, Report of the Commission of Inquiny into Matsers Relating to the Safety of the Public Drinking Water in the City of North Balleford, Saskaschewan (Regina: The Commission, 2002) (Chair: Robert D. Laing).

Public concern over these issues has lead to investigations by government and policy researchers. Set c.g. CFIA, Report on Levels and Incidences of Pesticide Residues in Selected Agricultural Food Commodities Available in Canada During 1994-1998 (6 November 1998), online: CFIA <http:// www.inspection.gc.ca/english/fssa/microchem/resid/1994-1998/94-98-0e.shtml>; Health Canada, Biotechnology and Human Health: Safeguarding and Enhancing the Health of Canadians (2005), online: Health Canada <http://www.hc-sc.gc.ca/sr-sr/alt_formats/hp/b-dgpsa/pdf/pubs/hio_hum_hcalsante_e.pdib; North-South Institute, Migrant Workers in Canada: A Review of the Canadian Seasonal Agricultural Workers Program by Maxwell Brem (Otlawa, North-South Institute, 2006), online: NorthSouth Institute <http:/www.nsi-ins.ca/english/pdf/MigrantWorkers_Eng_Web.pds. For example, milk is required to pasteurized in Canada, only approved agricultural chemicals can be used on crops, and perishable food such as milk and eggs must be sold with best before dates listed. Food and Drug Regulations, C.R.C. c. 870; Consumer Packaging and Labelling Regulations, C.R.C. c. 417.

Supra note 2. 
as feed, fertilizers, pharmaceuticals, and pesticides that are used in the production of the raw farm product by the farmer.

Theoretically, traceability could extend to the final consumption of the product, although, at this time, the steps between retail purchase and consumption have not been included in traceability programs for food. Instead, governments and the food industry rely on selfreporting by consumers to monitor concerns that arise after the consumer's purchase of the product. ${ }^{\text {it }}$

Depending on its design, a traceability program can be broad or rather limited in its scope. For example, a limited traceability program may have the sole objective of tracking the movement of a farm product from the farm to the processor or from the processor to the retailer. Alternatively, a traceability program may be a component of a broader scheme with a number of objectives such as tracking not only the movement of the farm product, but also the processing methods used to create the final product. Whether a traceability program is broad or limited in scope depends upon the consumer-driven goal the traceability program is trying to achieve. ${ }^{17}$

Essentially, traceability is a response to the interest of consumers regarding how and where their food is grown as well as concerns with respect to food safety. In other words, traceability programs have two objectives. First, traceability programs are designed to provide information to consumers about product origin, production methods, post-production attributes of the product, and desirable product traits. Second, traceability programs are designed to promote food safety.

\section{A. IDENTITY Preservation}

As stated, traceability programs may be designed to provide information to consumers about the food they eat. To understand this objective, it is necessary to examine a number of key concepts used by the agricultural sector. Identity preservation is one of these key concepts.

Identity preservation is a means of distinguishing goods in the marketplace based on unique characteristics, and it is one of the goals of traceability. The purpose of identity preservation is to establish a market niche. ${ }^{18}$ Identity preservation is narrowly defined in the

Health Canada monitors consumer product safety and operates regional Public Safety Bureaus to address consumer reports of problems. Reports can be made online at Health Canada <http:/www.hcsc.gc.ca/home-accueil/contacthecs-dgsesc/pso-bsp_ncr-ren_c.html $>$. Likewise, it is required that all prepackaged product contain the contact information of either the manufacturer or distributor of the product to facilitate consumer reports. See Consumer Packaging and Labelling Act, R.S.C. 1985, c. C.38, s. 10 [CPLA].

17 United States Department of Agriculture (USDA), Traceability in the U.S. Food Supply: Economic Theory and Industry Situdies (Agricultural Economic Report Number 830) by Elise Golan at at. (Washington: Economic Research Service, 2004), online: USDA <hitp:/www.ers.usda.gov/ publications/aer830/aer830.pdis at 4 .

18 The $A P F$ distinguishes between "identity preservation" and "traceability." However, this article posits that the former is a subset of the latter. This approach is not without precedent as no consensus has cmerged as to the definition of traceability: see Jill E. Hobbs et al., "Traceability in the Canadian red meat sector: do consumers care?" (2005) 53 Canadian Journal of Agricultural Economics/Revuc canadienne d'agroeconomie 47 at 50 . 
$A P F$ as "a 'closed loop' channel that facilitates the production and delivery of an assured quality by allowing traceability of a commodity from the germplasm, or breeding stock, to the processed product on a retail shelf."19 The $A P F$ is driving the creation of a number of traceability programs. However, farmers are also participating in a variety of additional traceability programs which have unexplored on-farm implications. ${ }^{20}$ Therefore, a broad understanding of identity preservation that considers not only issues of quality but also product origin and production method is needed to appreciate the on-farm implications of traceability programs.

Identity preservation is required where a consumer is unable to readily ascertain a unique characteristic of a product on her own. These characteristics are commonly called credence attributes as opposed to experience attributes. ${ }^{21}$ With an experience attribute, a consumer can identify the characteristic a product claims to possess simply by using the product. ${ }^{22}$ For instance, if a label indicates that a package contains frozen whole green beans, the consumer can readily verify that the beans are whole once the package is opened. Similarly, a consumer who purchases an over-the-counter allergy remedy that does not relieve her symptoms will know from experience that the attribute "relieves allergy symptoms" is incorrect. It is clear that a consumer can discem the accuracy of a label with respect to experience attributes without the assistance of an identity preservation system.

In contrast, credence attributes cannot be verified through experience. Instead, consumers must rely on traceability systems to verify the attribute's presence in the product. ${ }^{23}$ For example, strawberries from Mexico are indistinguishable from strawberries grown in Canada. As a result, a consumer must rely on the label to determine where the strawberries were grown. In order to preserve the identity of credence attributes, a system is needed that keeps products with these attributes separate from products without these attributes.

There are four categories of credence attributes that employ traceability systems to communicate their presence in a product to consumers. These categories are product origin, production method, post-production attributes, and product traits. Although presented as insular categories, it should be noted that there is often significant overlap between the categorics.

\section{PRODUCT ORIGIN}

Country of Origin Labelling (COOL) is the most basic form of an identity preservation system. ${ }^{24} \mathrm{COOL}$ is designed, of course, to distinguish the location of production. Numerous

Supra note 2.

Many farmers arc involved in production or marketing practices aimed at adding value to their product. For example, a certified organic farmer or a farmer who is producing under contract for a specific buyer will have traccability requirements in order to maintain his certification or med the requirements of his production contract.

Hobbs et al. supra note 18 at 48.

lbid. at n. I.

tbid.

COOL labelling merely requires a product's country of origin be tracked as opposed to a more complex traceability system that requires a farmer to track such things as source of and application dates of inputs used, visitors to the farm, and planting and harvesting practices. 
countries, including Canada, require certain agricultural products to indicate the country of origin at the retail level. Canada's Consumer Packaging and Labelling Act requires that a consumer faced with a selection of produce at the supermarket be informed of the product's country of origin either by a label on the product or on the bin where loose produce is displayed. ${ }^{2 s}$ The labelling of fresh fruits and vegetables is the most visible example of COOL under the CPLA. Traceability systems which achieve identity preservation based on location of production provide specific information to consumers about the origins of the food they eat. Accordingly, a Canadian consumer may knowingly choose an apple from China or spinach from the United States.

In addition to the basic COOL, the World Trade Organization (WTO) has established geographical indications to protect the use of place names in association with the sale of distinct goods originating from protected regions. These protections are outlined in the WTO Agreement on Trade-Related Aspects of Intellectual Property Rights. ${ }^{26}$ Champagne and Dijon mustard from France and Charlevoix lamb from Quebec are examples of products marketed with the use of a geographical indication. As a result of TRIPS, similar products produced outside protected regions are not permitted to use the names Champagne, Dijon, or Charlevoix.

\section{PRODUCTION METHOD}

The second type of identity preservation system distinguishes the production method utilized to create a product. Such a system can specify the manner in which a product was made and by whom. In the agri-food sector, traceability programs that indicate animal husbandry techniques are a common use of identity preservation. Labels that identify freerange chickens or eggs are used to distinguish products from those that were produced in close confinement such as in an intensive livestock operation. By including information about production methods on the label, sellers hope that consumers' concerns for animal welfare will translate into a willingness to pay more for products produced by less objectionable means. Identity preservation is also a means of delineating those products in the marketplace that have been created using organic production methods. Products labelled "Natural" or "Pesticide-Free" communicate to consumers that the products were not produced using chemicals, antibiotics, or other non-naturally occurring additives.

\section{POST-PRODUCTION ATtRIBUTES}

Post-production attributes are characteristics associated with how the product reaches the consumer after production and manufacturing. Identity preservation programs implemented to support a Fair Trade label are examples of programs aimed at preserving the identity of a post-production attribute. ${ }^{27}$ The Fair Trade label indicates that the farmer received a fair regulation. Sec Fresh Fruil and Vegetable Regulations, C.R.C.. c. 285.

27 For more information sec online: Fairtrade Labelling Organizations (FLO) Intemational <hup://www.fairtrade.nel>. 
price from the distributor for the product. ${ }^{28}$ Although most commonly associated with coffee, the Fair Trade label and the identity preservation system that supports it are increasingly being used to market non-food products such as handmade crafts.

\section{Product Traits}

Product traits are specific food characteristics which some consumers desire. Identity preservation traceability systems are used to communicate to consumers that their food contains specific product traits. ${ }^{29}$ Product traits can overlap with the production method category as many product traits result from the production method. For instance, food that does not contain pesticides or pharmaceutical residues is a direct consequence of the manner in which the food was produced. These systems warrant a separate calegory because many of the consumers who desire products with certain product traits do so without an understanding that the trait is connected to a production method. These consumers merely want verification, for example, that their milk is free of bovine growth hormones, that their chicken breasts do not contain antibiotics, or that their baby food is free of pesticides.

\section{B. FoOd SAFETY}

The promotion of food safety is the second goal of traceability initiatives in the Canadian food sector. It is not surprising that interest in traceability has peaked since the discovery of BSE in Canada. ${ }^{30}$ As witnessed by many Canadian cattle ranchers, a perceived food safety crisis can have devastating effects upon an industry. To avoid the effects of a BSE-like incident, the Canadian food industry is striving to improve food safety practices and to communicate those improvements to consumers. Traceability programs are a key component of many industry-specific food safety strategies. Traceability supports the three objectives of food safety regulations: accountability, prevention, and containment.

Accountability is the first element of food safety regulations. Traceability supports the legal principle that a person who has suffered a wrong is entitled to be compensated for damages and loss suffered on account of another's wrongdoing. ${ }^{31}$ Without traceability, an innocent victim may not have a legal remedy as it may not be possible to identify the wrongdoer. With traceability, the farmer's identity can be tied to a product once it reaches the consumer. Thus, a consumer will know whom to pursue for compensation if the farmer's actions (while the product was in the farmer's control) caused the consumer harm.

If a food safety problem, such as contamination, can be traced to farms, farmers have an incentive to take steps to prevent the contamination in order to avoid liability to consumers.

Ibid.

FLO International, is the umbrella organization for the national labelling programs in various countries including Canada. Smalt producers and those who trude in their products must meet standards established by FLO Internutional. The standards are outlined based on the product involvel, but all require a price for the product that covers the cost of sustainable production. See FLO International, "Trader Standards" (8 September 2007), online: Flo International <http://www.fairtrade.nev/rade_standards.html>.

Stupra note I.

livingstone v. Rawyards Cool Company (1880), 5 App.Cas. 25 (H.L.). 
By inserting accountability into food production, traceability may lead to increased prevention of food safety problems.

Traceability also assists with containment once food safety is compromised. If a product that poses a safety risk is produced in a system with traceability, the product can be traced through retailers and processors to the farm of origin in order to identify the source of the food safety concern. If the source of the concern can be readily ascertained, an effective recall can be initiated for all products that came in direct contact with the contaminated product during and after the problem arose. Traceability reduces economic waste by allowing the recall to be precise so as to avoid the unnecessary recall of products that do not pose safety risks.

The role of traceability in communicating safety to consumers may be as important as its role in promoting food safety. The ability to trace a product back to its source may instill consumer confidence, particularly if the product has been produced in an industry where food safety is known by consumers to be problematic. From an industry perspective, it is interesting to note, however, that at least one study finds that consumers are likely to value traceability initiatives supported by quality verification more highly than those that merely trace the product back to its farm of origin. ${ }^{32}$ As a result, while bare traceability may result in safer food by making those involved in bringing the food to the consumer's table more vigilant in monitoring safety, consumers may not be willing to pay more for that improvement without additional quality assurances.

\section{Operation of Traceabil.ity Programs}

An effective traceability program links a farmer to the consumer through extensive record keeping and documentation of production methods and product handling. All traceability programs, regardless of the commodity involved, require accurate and thorough recordkeeping by the farmer. However, the specific recordkeeping requirements of a traceability program differ depending on the commodity involved. An effective traceability program for cattle, for example, will require the farmer to maintain ancestry records, birth records, documentation of immunization and health checks, feed records, and an accounting of movement on and off the farm. A traceability program for cattle will also need to track animal-to-animal contact. In contrast, an effective traceability program for grain will require the farmer to maintain seed records, including information about where the seed was purchased and planted, records of chemical application, and information about grain storage. Some traceability programs for grain may also require unique genetic markers on the seed in order to indicate the farm of origin.

Most existing traceability programs are in their infancy. Traceability programs continue to evolve as farmers gain experience with traceability and the needs of industry and consumers change. It is the goal of the $A P F$ that 80 percent of food produced in Canada be capable of being traced back to its farm of origin. ${ }^{33}$ At present, it is unknown how many Canadian farmers have developed traceability programs.

33 Supra note 2. 


\section{TRACEABILITY AND ON-FARM LIABILITY}

Many farmers fear that traceability will reveal inadvertent regulatory offences and negligent behaviour resulting in liability. ${ }^{34}$ Without traceability, farmers are often able to hide behind the shield of anonymity to avoid liability. In fact, there do not appear to be any regulatory prosecutions related to food safety against farmers or civil actions by consumers against farmers, with the exception of actions against farmers who directly market their products to consumers. ${ }^{35}$ Traceability will likely increase both regulatory prosecutions and negligence actions by consumers against producers. It may be the case, however, that a farmer will be able to avoid liability, provided that the farmer is participating in a traceability program designed with a consideration of the requirements of due diligence and reasonable care.

\section{A. REgulatory LiabiLity}

With the advent of traceability, farmers are increasingly concerned about regulatory liability. Many lawyers may be unfamiliar with the regulatory framework governing food and agriculture. An understanding of this framework assists one in appreciating farmers' concerns surrounding traceability. Although the discussion of the on-farm impact of traceability in this paper primarily focuses on consumer protection offences, the record keeping requirements of a traceability program may reveal additional regulatory violations by farmers such as inaccurate claims of income levels on applications for income support programs. Therefore, a brief overview of the regulatory framework for agriculture and food is provided below in order to highlight the vast exposure to regulatory prosecutions farmers face when participating in traceability programs. This overview provides a context for the subsequent analysis of the relationship between traceability and due diligence.

\section{OVERVIEW OF THE FEDERAL REgULATORY FramewORK}

Agriculture, like immigration, was outlined as an area of shared jurisdiction in s. 95 of the Constitution Act, $1867 .{ }^{36}$ Consequently, all levels of government are involved in monitoring how food is produced, processed, and made available to consumers in Canada. To analyze the relationship between traceability initiatives and regulatory prosecutions, it is appropriate to focus on the federal regulatory scheme for agriculture and food. Despite the shared jurisdiction, nearly all reported prosecutions of offences related to agriculture and food involve federal offences arising from Canadian Food Inspection Agency (CFIA)

14 This study originated after discussions between the author and the executive of the Saskatchewan Mustard Development Commission about their members concem about the on-farm implication of a traccability.

is For examples of prosecutions of farmers involved in direct marketing, sec CFIA, Prosecution Bulletin, "\$3,600 fine for the sale of honey containing sugar from cane/com" (20 December 2004), online: CFIA <http:/www.inspection.ge.ca/english/corpaff/projud/2004/20041220be.shtml>; CFIA, Prosecution Bulletin, "Québec Man Fined for Oflences under the Maple Producfs Regulaitons" (31 January 2006), online: CFIA <http:/www.inspection.gc.ca/english/corpaftr/projud/2006/2006013 le.shtml>. 
investigations. ${ }^{37}$ Any conclusions about on-farm impact of traceability regarding federal regulatory offences can be applied to provincial regulatory offences.

Federal regulations targeting agriculture and food can be divided into two categories, namely legislation aimed at the needs of farmers and legislation that has consumer protection as its goal. It is important to highlight, however, that, in addition to regulations specifically targeting agriculture and food, the federal government's regulatory regimes for international trade and the environment directly impact agriculture. As the agriculture and food sectors are generally not targeted directly by these international regulations, they are not discussed in the following overview of the federal regulatory framework for food and agriculture in Canada.

\section{a. Federal Legislation Addressing Needs of Farmers}

Legislation aimed at the needs of farmers includes marketing legislation. The Canada Grain $A c t^{38}$ establishes a mandatory state-trading enterprise for most wheat and barley grown in Canada. Similarly, the Canada Agricultural Products Act ${ }^{39}$ mandates a system of supply management, or quotas, for products such as dairy, chicken, and eggs.

Legislation aimed at the needs of farmers also includes income stabilization and debt management legislation. The Farm Income Protection $A c f^{\circ 0}$ is an example of legislation explicitly addressing farmers' needs for income stabilization. The CGA and the CAPA also have an income stabilization objective by restricting the total amount of products available for sale. "' The Farm Debr Mediation $A c d^{2}$ is debt management legislation in that it requires farmers and their lenders to work towards a negotiated debt repayment plan.

Another type of legislation addressing the specific needs of farmers concerns the efficacy and quality of inputs used in production. This category of legislation is often aimed at those who have a business relationship with farmers. For example, the Seeds $\mathrm{Acr}^{3}$ prohibits the sale of unregistered seeds. The registration process requires proof of efficacy and quality. Similarly, the Fertilizers $\mathrm{Act}^{44}$ mandates registration to ensure that products perform as described and do not harm the crops to which they are applied. The BSE crisis underscored the importance of the composition and quality of feed. The Feeds $A c c^{45}$ also requires registration and conformity with prescribed standards for any feed sold or imported in Canada.

Sce e.g. Isoporc Inc. v. Canada /Canodian Food Inspection Agency), [2006]C.A.R.T.D. No. 19 (Canada Agricultural Review Tribunal); Chan v. Camada (Canadion Food Inspection Agency), [2004] C.A.R.T.D. No. 29 (Canada Agricultural Review Tribunal).

R.S.C. 1985. c. G-10 [CGA].

R.S.C. 1985 (4th Supp.), c. $20[C A P A]$.

S.C. 1991 , c. 22.

Ste CGA, supra note 38, s. 44; CA 'A, supra note 39. ss. 17-18.

S.C. 1997, c. 21 .

R.S.C. 1985, c. S-8, s. 3.

R.S.C. 1985, c. F-10, s. 4.

R.S.C. 1985 , c. F-9, s. 3(1). 
The final category of federal legislation designed to respond to farmers' needs is legislation with either a plant or animal health objective. The Health of Animals $\mathrm{Acr}$ it and the Plant Protection $\mathrm{Act}^{47}$ are examples of legislation which aim to prevent and contain disease and pests on the farm. An obvious reason for this type of legislation is to avoid risks to human health. Disease and pests, however, can negatively affect producer yields and result in lower prices and lost market opportunities. A disease or pest can also jeopardize breeding or seed stock. Many farmers have spent years developing unique traits in animals and plants. These efforts can be lost if the affected plant or animal is required to be destroyed. Thus, in addition to consumer protection objectives, legislation with either a plant or animal health objective is designed to respond to the needs of farmers.

All federal legislation aimed at the needs of farmers contain regulatory offences for noncompliance. The broad reach of regulations addressing farmers' needs underscore why farmers are concerned with the liability implications of traceability. As previously stated, traceability programs have thorough record-keeping requirements. By participating in traceability programs, farmers face the increased risk that the commission of a regulatory offence will be documented and subsequently revealed.

\title{
b. Federal Legislation Aimed at Consumer Protection
}

Canada's federal regulatory framework with respect to agriculture and food also includes legislation aimed at consumer protection. The federal government's consumer protection efforts in the agriculture and food sectors are principally targeted at food safety and retail fraud. The Food and Drugs $A c f^{18}$ and the $C P L A^{49}$ are the most important federal statutes in the area of consumer protection.

The FDA has broad application. It defines "food" as including "any article manufactured, sold or represented for use as food or drink for human beings, chewing gum, and any ingredient that may be mixed with food for any purpose whatever." ${ }^{\text {"To }}$ The $F D A$ prohibits the sale of food that:

(a) has in or on it any poisonous or harmful substance;

(b) is unfit for human consumption;

(c) consists in whole or in part of any filthy, putrid, disgusting, rotten, decomposed or diseased animal or vegelable substance;

(d) is adulterated; or

(e) was munufactured, prepared, preserved, packaged or stored under unsanitary conditions. 51

\author{
S.C. 1990 c. 21. \\ S.C. 1990, c. 22. \\ R.S.C. 1985, c. F-27 $[R D A]$. \\ Sipra note 16. \\ Supra note 48, s. 2. \\ Ibid.. s. 4(1).
}


In addition, it is an offence under the $F D A$ to "label, package, treat, process, sell or advertise any food in a manner that is false, misleading or deceptive or is likely to create an erroneous impression regarding its character, value, quantity, composition, merit or safety."

The CPLA standardizes the packaging and content of labels required on pre-packaged food products sold to consumers in Canada. By standardizing this information, consumers are better able to compare the attributes and value of like products on the supermarket shelf. Furthermore, consumers are protected against deliberate or inadvertent fraud by processors and retailers. Under CPLA, it is an offence to make "false or misleading representation[s]" on a food label, ${ }^{33}$ or to sell products that do not meet the packaging requirements or net quantity requirements outlined in the legislation. ${ }^{54}$ Provided that a farmer's product is either processed or repackaged, or both, before it is sold to retail consumers, the packaging and net quantity requirements of the CPLA are likely of little concern to farmers. The potential for a regulatory violation arises, however, if a farmer participates in a misleading or false label claim. For instance, a processor may rely on a farmer's claim that the product is free of pesticides when the product is labelled for sale. If that information is false, the farmer may be prosecuted pursuant to CPLA."s

The categories of consumer protection regulations outlined above are not rigid. Ensuring that a consumer is not misled about the origin or content of food based on the label may also have a food safety objective. For instance, avoiding spinach from the United States was particularly important to the safety of Canada's food supply during the recent $E$. coli outbreak. Without information about product origin, it would have been impossible to identify and remove potentially harmful products from supermarket shelves.

As the following discussion of jurisprudence demonstrates, historically, only processors and retail sellers of food products have faced prosecution under federal consumer protection legislation. ${ }^{56}$ This is likely due to the difficulty in linking a product sold to consumers to the farm where the product originated. The lack of prosecutions against farmers under federal consumer protection legislation may change with the development of traceability programs. If traceability removes anonymity in the food supply chain, farmers will likely begin to face prosecutions for consumer protection offences.

\section{Categories of LIABILITY}

In all likelihood, traceability programs will increase the risk of regulatory prosecutions against farmers. As outlined above, farmers participating in traceability programs may be prosecuted under a broad range of federal regulatory offences.

In R. v. Sault Ste. Marie (City of), the Supreme Court of Canada established three categories of liability for regulatory offences: mens rea, strict liability, and absolute liability 
offenses. ${ }^{57}$ To be convicted of a mens rea offence, the Crown must establish that a farmer knowingly engaged in the prohibited conduct or that the farmer was reckless in the sense that the farmer ought to have known that the conduct was prohibited. ${ }^{58}$ With respect to absolute liability offences, mere proof of commission of the offence, regardless of intent or due diligence exercised, is sufficient to find liability. ${ }^{59}$

Strict liability offences lie in between the mens rea category and the absolute liability category. Strict liability offences permit a defence of due diligence. The Crown must first establish that the offence has been committed. The person charged with the offence can then present a defence of due diligence in an attempt to avoid liability. ${ }^{60}$ The vast majority of offences related to agriculture and food will likely be interpreted by the courts as strict liability offences. Therefore, in analyzing the impact of traceability on farmers, it is appropriate to focus on the relationship between traceability and the defence of due diligence in strict liability offences.

\section{a. Due Diligence}

A review of prosecutions involving consumer protection offences provides some guidance into what a farmer must do to establish due diligence if facing prosecution. This guidance is admittedly limited as a consequence of the relatively few consumer protection prosecutions in Canada to date. Furthermore, there is a tendency for those charged with a consumer protection offence related to agriculture and food to plead guilty. ${ }^{61}$

In Sault Ste. Marie, the Supreme Court outlined that a due diligence defence is available "if the accused reasonably believed in a mistaken set of facts which, if true, would render the act or omission innocent, or if he took all reasonable steps to avoid the particular event."62 Since Sault Ste. Marie, Canadian courts have examined what steps have to be taken by the defendant to establish due diligence. In $R$. v. Bata Industries $L i d .{ }^{63}$ for example, the Court held that what is reasonable and foreseeable should be assessed in the context of the particular industry or the specific accused. ${ }^{64}$

Canadian courts have applied this jurisprudence to assess whether a due diligence defence has been established in prosecutions of consumer protection offences. For example, the issue of what is reasonably foreseeable was raised in Karmali. ${ }^{65} \mathrm{Mr}$. Karmali purchased the assets of an agricultural chemical supply business in a bankruptcy sale. He was told by the Registrar in Bankruptcy that he also acquired all the requisite approvals to sell the pesticides when he purchased the business. At a subsequent meeting with a federal investigator,

[1978] 2 S.C.R. 1299 [Sault Ste. Marie].

lbid. at 1309-10.

lbid. at 1310 .

thid. at 1313.

Very few prosecutions are reported, but the CFIA publishes reports of their prosecutions. See CFIA. "Prosecution Bulletins" online: CFIA <http://www.inspection.gc.ci/english/corpaffr/projud/projude. shtml>. A quick review of these bulletins reveals an overwhelming majority of guilty pleas.

thid. at 1326.

(1992), 9 O.R. (3d) 329 at 358 (Prov. Ct.).

thid. at 345.

Karmali, supra note 56. 
Karmali was informed that the pesticide he purchased lacked the required approvals; he immediately stopped selling the pesticide. Nevertheless, Karmali was charged under the Pest Control Products Acth with selling unregistered pesticides. In his defence, Karmali argued that he had acted with due diligence.

In its decision, the Ontario Provincial Court held that "various factors ... determine what a reasonable standard of care is in the circumstances of any particular case, including such factors as the activity being regulated, the risks involved, the likelihood of harm, the gravity of harm, any potential benefits, and the degree of knowledge or skill expected of the accused." ${ }^{17}$ Ultimately, the Court concluded that Karmali excrcised due diligence when he reasonably relied on the Registrar in Bankruptcy's assurances. No evidence was presented concerning the likelihood and gravity of harm. Although not explicitly stated, the Court highlighted that Karmali's involvement in the farm chemical business was limited. ${ }^{68}$ Therefore, one can infer that his lack of expertise contributed to the finding that Karmali's reliance on the Registrar in Bankruptcy was reasonable.

R. v. Stars Trading $\mathrm{Co}^{69}$ also examined due diligence in the context of a consumer protection offence. The British Columbia Supreme Court held that the "potential results from that behaviour are relevant in a determination of what is reasonable under the circumstances." ${ }^{\prime 70}$ At trial, the defendant company was acquitted of charges under $\mathrm{ss.} 5(1)$ and 31.1(a) of the $F D A$ that it sold coconut juice with "false or misleading labels."' The labels failed to list sulphites, a known allergen, in the ingredient list. The Court found the trial judge's decision that the defendant company exercised due diligence was unreasonable: the fact that sulphites were known to be an allergen and that the company had been warned about mislabelling its products in the past created a positive obligation to obtain a list of ingredients to ensure the label was accurate. ${ }^{72}$

In R. v. Can-na Foods-2 Lid., ${ }^{73}$ the defendants were convicted under s. 5 of the FDA of mislabelling and selling packages of meat. The defendants mislabelled packages of horsemeat as "beef." ${ }^{74}$ Despite the fact that they had been wamed prior to being charged, the defendants unsuccessfully attempted to avoid liability by claiming that they were unfamiliar with applicable labelling regulations. ${ }^{75}$ The decision in Can-na Foods suggests that, when participating in a regulated industry, due diligence includes a positive obligation to become familiar with the applicable legislation. In addition, the Alberta Provincial Court stressed that, if alerted to a potential violation, due diligence requires that a defendant undertake the steps necessary to ascertain if he is in compliance with the regulations. ${ }^{76}$

R.S.C. 1985 , c. P-9, s. 11 (1), as am by S.C. 2002 , c. 28 , s. 6.

Karmali, supra note 56 at para. 27, citing R.v. Shell Canada Lid. (1999). 253 A.R. 143 (Prov. Ct.).

lbid. at paras. 31-33.

2003 BCSC 833 [Stars Trading].

lbid. at para. 34 .

Ibid. at para. 1.

Ibid. at para. 40.

Can-na Foods, supra note 56.

libid. at para. 3.

Ibid. at para. 44.

Ibid. at paras. 45-46. 
In $R$. v. Campbell," however, the reasonable, albeit mistaken, belief that one is in compliance with the applicable regulations was sufficient to establish due diligence. In this case, the defendant seed grower mislabelled the weight of seeds he was distributing. An Agriculture and Agri-Food Canada inspector gave notice that the lot of seeds from which the mislabelled bags were found had been detained. Nevertheless, the defendant shipped a significant portion of the seed to an American customer. Relying on the statement by the court in Sault Ste. Marie that the due diligence defence "will be available if the accused reasonably believed in a mistaken set of facts which, if true, would render the act or omission innocent," ${ }^{, 78}$ the Saskatchewan Provincial Court found that Mr. Campbell's belief that the bags were accurately weighed because his bagging scale was regularly inspected by govemment officials was reasonable. Campbell was aware of the regulations, but he avoided liability because he mistakenly believed that he was in compliance. ${ }^{79}$

In R. v. Steinberg's $L t d,,^{80}$ the defendant was charged with mislabelling a cut of beef in a pre-packaged product contrary to $\mathrm{s} .7$ of CPLA. On at least two occasions, a cut of beef of lower quality was labelled as a cut of higher quality by the defendant. Nevertheless, the Ontario Provincial Court held that the defendant exercised due diligence as the defendant had designed

an elaburate scheme of employee training and education as to govemmental regulations and requirements, and compliance therewith - this included manuals, oral expositions, direct discussions with affected personnel both as individuals and at group meetings; an on the job site inspection scheme, designed to accustom every employee concerned with the marketing of meat to inspect the meat counter at regular and irregular intervals - even directors and senior "head office" personnel of the company were instructed as to this, as of course were store managers, meat managers and meat packers. ${ }^{81}$

The Court in Steinberg further explained that due diligence requires "precaution sufficient to prevent the foreseable, but not the unforeseen, the unexpected, the unknown, or the unintended." $" 82$

A similar conclusion about the extent of due diligence required by a defendant was reached in $R$. $v . A \& A$ Food $L t d{ }^{83}$ In this case, the defendant was charged under $\mathrm{s}$. $5(1)$ of the $F D A$ with possessing and marketing unlabelled Monterey cheese packed in bulk. In convicting the defendant, the British Columbia Supreme Court upheld the decision of the trial judge, finding that the presence of unlabelled cheese in the defendant's warehouse was a likely occurrence and, therefore, foreseeable. The Courts held that the defendant's failure to have a system in place to deal with this eventuality was inexcusable. ${ }^{84}$

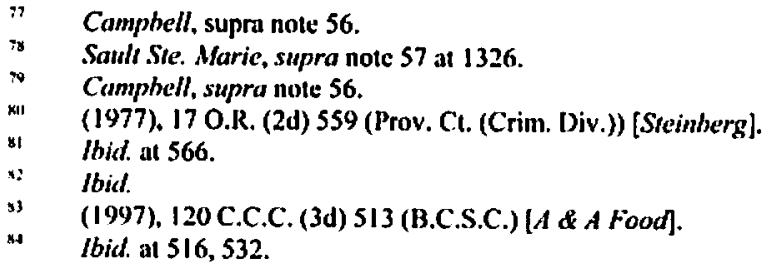


Similarly, the defendant company in $R$. v. Salerno Dairy Products Ltd. ${ }^{85}$ was unable to avoid conviction because it failed to act after a regulatory infraction was specifically drawn to its attention. In this case, a letter from federal officials which outlined that Salerno's grated parmesan cheese contained prohibitively high lactose levels generated no action by the defendant company. Thus, the Alberta Provincial Court held that the defendant was unable to rely on the defence of due diligence. ${ }^{86}$

R. v. $A \&$ A International Industries $I n c{ }^{87}$ further discusses what systems are expected to be in place to ensure regulatory compliance. The Alberta Provincial Court held that the defendant company failed to establish due diligence because it did not have a system in place to ensure that ingredients used in its product complied with the applicable regulations. ${ }^{88}$ The company had labelled and sold cheese as Parmesan cheese despite the presence of high levels of lactose. The high lactose levels indicated that the Parmesan cheese had been mixed with other milk products and was, thus, a cheese blend. The fact that customers did not complain about the adulterated product did not save the defendant from conviction. ${ }^{89}$

R. v. Westfair Foods $L t d^{90}$ provides an interesting analysis of what is required by a defendant once a system is put in place to address a known problem. On a number of occasions and in a number of Westfair stores, federal officials found packages of meat on grocery shelves with improperly labelled weights. The products' labels suggested that the packages contained twice the product that was present. Customer complaints and federal inspections drew this problem to Westfair's attention. Westfair's management reviewed the situation and circulated memorandums to workers and spoke with supervisory staff about changes in packaging and labelling protocols to correct the problem. The trial judge held that Westfair had acted with due diligence." This decision, however, was reversed by the Manitoba Court of Queen's Bench, which held that due diligence requires the defendant to both ensure that the new protocols are being implemented and that they are effective in correcting the problem. ${ }^{92}$ The Court of Appeal restored the trial judge's decision, holding that some action, even if ineffective, can satisfy the requirements of due diligence. ${ }^{93}$

The decision in another case involving Westfair Foods reveals that courts will also consider industry norms when assessing due diligence. ${ }^{94}$ In this case, rather than specifying the actual weight of packaged meat products, Westfair labelled the packages with a "minimum net weight." Westfair cited a tendency for the products to lose moisture over time as its rationale for this non-conforming label. In convicting Westfair of violating the

(1995), 173 A.R. 153 (Prov. C1.) [Salerno].

lbid. at paras. 31-33.

1998 ABPC 60, 224 A.R. I42 [A \& A Inclustries].

Ibid. at para 7 .

lbid. at para 8.

(1988), [1989] 1 W.W.R. 152 (Man. Q.B.) [Westfair / (Q.B.)]. rev'd [1989] S W.W.R. 278 (Man. C.A.)

[Westfair / (C.A.)].

Wesifair / (Q.B.), ihid, referring to reasons of the trial judge, Lismer J.

Ibid. at 157.

Westfair / (C.A.), supra note 90 at 278.

R. v. Westfair Foods, [1996] 8 W.W.R. 372 (Man. Q.B.), affd [1997] 6 W.W.R. 462 (Man. C.A.) [Westfair 2].

Ibid. at 374. 
labelling requirements of s. 4 of the CPLA, the Manitoba Court of Queen's Bench noted that other retailers encountered the same problem with moisture loss, but were able to accurately label their products. ${ }^{96}$ The failure to conform to customary industry practice resulted in the Court's finding that Westfair did not act with due diligence.

\section{b. Relationship Between Due Diligence and On-farm Impacts of Traceability}

Although it appears that farmers have not been the target of prosecutions for consumer prolection offences to date, this may change in the future with the emergence of traceability programs. Thus, it is useful to review the standard of due diligence which has been developed by the courts with respect to agriculture and food regulations. Understanding how due diligence has been approached by the courts can provide some insight into the standard farmers can expect to meet in order to rely on the defence of due diligence. This understanding can also provide insight into what role participation in a traceability program can play in a farmer's due diligence defence.

From the few reported cases that discuss due diligence in the context of agriculture and food regulations, farmers can expect that the standard of due diligence they will be required to establish will differ depending on the particular offence. For example, food safety offences that may result in harm to human health will likely require a higher level of due diligence than a violation of a regulation concerning record keeping. Stars Trading ${ }^{97}$ specifies that the content of a due diligence standard will vary depending on the likelihood and gravity of harm that may result or has resulted as a consequence of the defendant's action.

Furthermore, it is unlikely that farmers will be able to simply state that they did not have any knowledge of the applicable regulations in order to avoid liability. Indeed, the decisions in Can-na Foods ${ }^{98}$ and Campbell" suggest that farmers have a positive obligation to become familiar with all regulations that apply to their farming operations. Clearly, ignorance of the law will not be a defence to regulatory prosecution for farmers. Depending upon the specific commodity involved, a traceability program should familiarize those involved with the operation with the governing rules and regulations, train employees to implement the program, and establish regular monitoring and inspection of the system.

To establish due diligence, Canadian jurisprudence further suggests that a traceability system should consider not only the end product, but also the inputs that are used to create the final product. For instance, a farmer should ensure that seed, feed, fertilizers, and supplements are registered and approved for the use to which they are being put. Both $A \&$ $A$ Food $^{100}$ and Salerno ${ }^{101}$ suggest that the design and implementation of a traceability program should consider and establish protocols to address foreseeable problems. Moreover, if a farmer becomes aware of the problem, due diligence requires that farmer to respond. 
Perhaps most importantly, Canadian jurisprudence suggests that the absence or presence of a system to monitor production, minimize problems, and to ensure regulatory compliance may be the key consideration in determining whether a farmer has acted with due diligence. Steinberg supports the assertion that a traceability program, while facilitating on-farm consumer protection prosecutions, may establish a defence of due diligence. ${ }^{102}$ Moreover, if the adoption of traceability programs becomes an industry norm, Westfair 2 appears to indicate that the failure to have an on-farm traceability program will be strong evidence of a lack of due diligence on the part of the farmer. ${ }^{103}$

It is important to note, however, that Wesffair / (C.A.), the only appeallate decision that discusses due diligence in the context of these consumer protection offences, seems to suggest that a traceability program need not be overly complex and elaborate. ${ }^{104}$ At least in regard to issues of consumer fraud, the Manitoba Court of Appeal appears to suggest that the mere existence of a system, even if it is not 100 percent effective, meets the requirements of due diligence. ${ }^{105}$ The Manitoba Court of Appeal's ruling is consistent with the sentiments expressed in Steinberg that it is not realistic to expect that consumers be protected against all possible harm.

After reviewing existing jurisprudence regarding the prosecution of consumer protection offences, it is reasonable to conclude that, ultimately, the impact of traceability upon regulatory liability for farmers may not be significant. While traceability may reveal evidence of statutory non-compliance, farmers will likely be able to rely on their traceability program to establish due diligence. Thus, a farmer who has implemented a traceability program will likely be able to avoid conviction.

\section{B. TORT LIABILITY}

As with regulatory liability, civil liability in negligence may increase when the protection afforded by anonymity is removed in accordance with a traceability initiative. A consumer may be entitled to compensation if she establishes that she was injured or suffered a loss as a result of something she ate. A producer may be responsible for compensating the victim for all or part of his damages if the consumer establishes that the harm was related to the producer's actions and the producer cannot prove that he exercised reasonable care.

Unlike the regulatory framework governing food and agriculture, the law of negligence is well understood. Thus, it is unnecessary to review the content and requirements of a successful negligence action in order to understand the on-farm implications of traceability in negligence liability. Clearly, if faced with a negligence action, a defendant farmer will be held to a standard of reasonableness. ${ }^{106}$ Arguably, the reasonableness standard will resemble the requirements of a successful due diligence defence in a regulatory prosecution. Specifically, the absence or presence of an on-farm traceability program may be relevant to 
reasonable behaviour, especially if traceability programs become a customary practice among farmers. Although it is unnecessary for the purposes of this paper to discuss the specific requirements of a negligence claim, a review of litigation trends from consumer initiated negligence actions in the agriculture and food sector provides insight into the on-farm impact of traceability.

Tort liability in the food sector, however, is nothing new. Few lawyers need to be reminded that the basis of modern negligence law throughout the Commonwealth can be traced back to a case involving a decomposed snail in a bottle of ginger beer. ${ }^{107}$ Recently, however, a number of high-profile American cases have created the perception that the food industry is facing a rapidly increasing amount of lawsuits by consumers who have been injured or sustained a loss as a result of unsafe or mislabelled food products. ${ }^{108}$ Particularly troublesome to Canadian farmers is the damages awarded in these American cases.

A discussion of litigation trends in Canada involving claims of negligence by consumers in the agriculture and food sector assists the analysis of the on-farm impact of traceability. A review of litigation trends evaluates the likelihood of a plaintiff's success and outlines the consequences to Canadian farmers of a finding of negligence.

\section{Litigation Trends}

There are relatively few reported decisions in Canada involving consumer initiated food safety litigation. The absence of reported decisions directly contradicts the perception that the number of personal injury cases resulting from food borne illnesses or mislabelling is on the rise in Canada. A conclusive assessment, however, of the number of consumer initiated negligence actions is difficult given that there are strong incentives for defendants to settle with the plaintiff before the case goes to trial. Many defendants are motivated to settle to avoid negative publicity. Defendants may suffer significant economic loss if consumers avoid the defendant's product out of fear. To avoid further publicity, these settlements are rarely made public. Consequently, analyzing litigation trends in this sector is challenging.

Nonetheless, some conclusions about the impact of traceability on on-farm tort liability are possible. First, the typical defendants in consumer lawsuits are food retailers, manufacturers, and distributors. In Vanek v. Great Atlantic \& Pacific Co. of Canada, ${ }^{109}$ the plaintiff drank a bottle of grape juice that was contaminated with a toxic fluid and sued the distributors of the contaminated juice. In Rene v. 7-Eleven Canada Inc., ${ }^{10}$ the plaintiff sued the convenience store where he purchased a sandwich that he alleged caused him to suffer from food poisoning. The plaintiffs did not name the farmers who grew the grapes or raised the beef in the lawsuit because, without traceability programs in place, there was no ability to trace the product back to the farm of origin.

Donoghue v. Stevenson, [1932] A.C. 562 (II.L.).

Sce c.g. Pelman v. McDonald's Corp., 237 F.Supp. $2 d 512$ al 538.39 (S.D.N.Y. 2003); Liebeck v. McDonald's Resfaurants, P.T.S., Inc., 1995 WL 360309 (N. Mex. Distr. Ct.); Kerri E. Machado. "Unfit for Human Consumption: Why American Beef is Making Us Sick" (2003) 13 Alb. L.J. Sci. \& Tech. 801. [1997] 39 O.T.C. 54 (Ct. J. (Gen. Div.)), rev'd on other grounds (1999), 180 D.L.R. (4th) 748 (Ont. C.A.). 2001 BCPC 186 (Civ. Div.). 
Furthermore, existing jurisprudence in consumer protection litigation suggests that causation remains a significant barrier to plaintiff success. In Jama (Litigation Guardian of) v. McDonald's Restaurants of Canada Lld.,"It the plaintiff alleged physical and psychological injury after eating a Big Mac containing a severed rat head. However, the Ontario Superior Court did not accept the plaintiff's evidence that the rat's head was in the burger when it was sold. ${ }^{112}$ Thus, the action failed because the defendant failed to provide the necessary evidence to establish causation. Likewise, in Andersson v. Loblaw Co. LId., 13 the plaintiff claimed she became ill after eating margarine purchased at the defendant's market. As in the Jama case, the plaintiff failed to establish causation. The plaintiff alleged that the margarine was improperly stored resulting in the growth of a toxic mould. The plaintiff's claim was rejected by the Ontario Court of Justice as he did not prove that the food was unfit for consumption thereby causing his illness. The Court held that the mould was of a non-toxic variety and, thus, could not be responsible for his illness. ${ }^{1 / 4}$

In addition, Canadian jurisprudence with respect to consumer-initiated negligence actions in the food sector indicates that damage awards are not excessively large. In Constant c. Motel Belvedere Inc., ${ }^{115}$ for example, the plaintiff immediately suffered convulsions and fell unconscious after eating food contaminated by an insecticide. The insecticide poisoning also resulted in various disorders and fatigue for the plaintiff. After considering the seriousness of his symptoms, the Court awarded what seems a rather modest sum $\$ 35,000$ for loss of physical integrity and $\$ 10,000$ for pain and suffering to the plaintiff. ${ }^{116}$

Carew $v$. Midway Gardens $L \imath d .^{117}$ is another example of a consumer-initiated negligence action where the plaintiff only received modest damages. In this case, the plaintiff sued a restaurant after eating a slice of pizza containing glass. The plaintiff alleged illness as well as anxiety after eating the adulterated pizza and the court awarded modest damages to the plaintiff totalling $\$ 1,500 .^{118}$

One of the largest damages awards in a negligence action by a consumer was awarded in Mustapha $v$. Culligan of Canada Lid. ${ }^{119}$ In this case, two plaintiffs found a dead fly and parts of another fly in a sealed bottle of water. The first plaintiff, Mr. Mustapha, alleged he had recurring nightmares about flies and could not sleep for more than four hours at time. As a result, he reported losing his sense of humour and becoming overly sensitive in dealing with others. He also reported that he was afraid to take showers and to drink water. Mustapha claimed that he required psychological care for his trauma and was prescribed medication which left him unfocused. He subsequently lost 60 percent of his clientele at his hair salon. The second plaintiff alleged reccurring nausea and vomiting. Ultimately, the Ontario Superior Court accepted that, although it was an unusual and "bizarre" response, the flies

[2001] O.T.C. 203 (Sup. CI.) [Jama].

ibid. at para. 12.

[1998] O.J. No. 1108 (Ct. J. (Gen. Div.)) (QL).

lbid. at paras. $45,51$.

(1988), [1990] 27 Q.A.C. 48 [Constam].

ibid. at para. 7 .

[1992] 99 NIId. \& P.E.I.R. 269.

ibid. at para. 7.

[2005] O.T.C. 276 (Sup. C1.). 
were partially the cause of the Mustapha's nervous shock. ${ }^{120}$ The Court awarded general damages of $\$ 80,000$, past and future special damages of $\$ 24,174.58$, damages for past economic loss of $\$ 122,400$, and damages for future losses of $\$ 115,200 .^{121}$ When compared with the injury suffered in Constant, the quantum of damages awarded in this case appears excessive and was, in fact, overturned on appeal. ${ }^{122}$ The Ontario Court of Appeal held that Mustapha's reaction to the dead fly was not reasonably foreseeable because it was so out of line with how an average person would react in the same circumstance. ${ }^{123}$ Culligan, therefore, was not found liable for Mustapha's injury. The ultimate resolution of this case should be determined shortly by the Supreme Court of Canada, as the application for leave to appeal was recently granted. ${ }^{124}$

The last trend to emerge from a review of Canadian jurisprudence on consumer initiated negligence actions in the food sector is the recent appearance of class action lawsuits as a consumer litigation strategy. Class actions are designed to provide access to the courts to individual plaintiffs for whom the cost of litigation is prohibitive. Class actions thus increase the amount of claims a defendant will face. The total damages awarded to any individual, however, do not appear to have been inflated in this process. For example, Fleetwood Sausage, a manufacturer of processed meat products, reached a settlement with 143 plaintiffs in a class action lawsuit. ${ }^{125}$ These plaintiffs had alleged that they were infected with improperly prepared sandwich meat. The manufacturer paid $\$ 4,000$ and all the document expenses of to each plaintiff who was not hospitalized. For those hospitalized under 30 days, the manufacturer paid $\$ 7,500$ plus all document expenses and $\$ 700$ for each day spent in the hospital. For those who required hospital stays over 30 days or with ongoing problems, settlements were reached through mediation or binding arbitration. The total settlement was expected to be under $\$ 1$ million. ${ }^{126}$

A lawsuit involving Maxim's Bakery, a manufacturer of processed baked goods, is another example of a class action lawsuit that reached a reasonable settlement with the plaintiffs who suffered salmonella poisoning traced back to unpasturized eggs used in Maxim's products. ${ }^{127}$ Hospitalized plaintiffs received settlements that compensated victims for their out-of-pocket expenses, lost wages, and the greater of $\$ 10,000$ or $\$ 6,500$ plus $\$ 600$ for each day spent in the hospital. Plaintiffs who were not hospitalized each received $\$ 3,750$ plus expenses. ${ }^{128}$

Ibid. at para. 180.

Ibid. at paras. 238, 240.

(2006), 275 D.L.R. (4th) 473 (Ont. C.A.).

Ibid. at para. 53.

Jbid., leave to appeal to S.C.C. granted, 31902 (21 June 2007).

David Hogben, "Sausage Maker Agrees to Pay $E$-Coli Victims: Fleetwood Sausage Reached Tentative Pact After 143 People Ate Tainted Sandiwish Meats" Vancouver Sun (I May 2005), online: Food Safety Network <http://www. foodsafetynetwork.ca/en/news-details.php?a=4\&c=30\&sc=218\&id $19999>$.

Jbid.

David Hogben, "Class-Action Pursued Against Richmond Bakery Over Poisonings" Vancouver Sun (2 May 2005), online: Food Safety Network <hitp://www.foodsafetynetwork.ca/en/news-details. php?a $=4 \& c=30 \& s c=218 \&$ id $=26265>$.

lbid. 
a. Relationship Between Litigation Trends

and On-farm Impacts of Traceability

After reviewing reported cases involving consumer initiated negligence actions in the agriculture and food sector, it is possible to conclude that farmers have not faced civil lawsuits in this area to date. This is likely due to the difficulty in linking farmers specifically to a contaminated food product. As traceability programs become the norm, however, farmers will lose the protection afforded by anonymity. It is not unreasonable to expect, with the advent of traceability programs, future plaintiffs or defendants will add farmers as named defendants in lawsuits in an attempt to avoid or apportion liability. Thus, it appears that the introduction of traceability programs will increase the risk of tort liability for farmers.

However, existing jurisprudence demonstrates that many plaintiffs have difficulty overcoming the causation stage of the negligence analysis. In other words, it will likely be difficult for a plaintiff to establish that a farmer's product caused the plaintiff's alleged illness or other loss. In food safety cases, the contaminated product is often entirely consumed, which makes tracing the origin of illness or injury difficult. Similarly, any one ingredient in processed food products is commonly a mixture of like products from a number of farmers. The scale of processing employed today requires amounts of single ingredients that are larger than can be supplied by any one farm.

In addition, farmers may benefit from the restrictive treatment of pure economic loss claims by the Canadian courts. Plaintiffs solely alleging a financial loss rather than a loss that is directly connected to a physical injury are required to establish more restrictive duties of care. ${ }^{129}$ Therefore, it may prove very difficult, for example, to successfully argue that a farmer is liable for the financial losses that an importer suffered when the processed food product the importer was trying to import was rejected by a foreign market as a consequence of a pesticide residue, even if the pesticide residue can be traced back to the farmer.

While these demonstrated difficulties in establishing negligence are likely good news for farmers, they may be required to incur significant legal costs in order to defend against negligence claims. The cost of defending against negligence claims is a significant downside associated with traceability programs.

Despite the relatively small amount of damage awards in Canadian negligence cases involving consumer protection issues, most farmers are not in a position to pay even a reasonable damage award in a case involving serious injuries. For farmers, this is a negative aspect of participating in traceability programs. From a legal and public policy perspective however, it is likely appropriate that a farmer, who has failed to exercise reasonable care and whose actions caused injury to an innocent victim, be responsible for compensating that victim. 


\section{Conclusion}

From one perspective, farmers will benefit from the adoption of traceability programs due to increased consumer confidence and increased sales of traceable products. Notwithstanding this argument, many farmers may resist the widespread adoption of traceability programs out of fear that traceability will increase on-farm liability. In particular, farmers are likely concerned with regulatory and tort liability.

A review of Canadian jurisprudence involving consumer protection offences and negligence claims in the agriculture and food sectors suggests that farmers have some reason to be concerned. Without traceability, it is nearly impossible to link a product to a farmer once it has left the farm and become commingled with like products in processing. Traceability will increase the likelihood that a farmer will face regulatory prosecutions as well as civil lawsuits initiated by consumers. As traceability programs become the norm, farmers will lose the protection granted by anonymity. Hence, traceability, by linking a product to a farmer until it reaches the consumer, extends a farmer's responsibility for the product.

While traceability may remove the protection from prosecution and negligence actions farmers once enjoyed, participating in traceability programs which trace all inputs and production processes used on the farm should result in more benefits than risks to farmers. Moreover, participating in a traceability program may assist a farmer in establishing that he acted with due diligence and reasonable care. Therefore, the overall on-farm impact of traceability will likely prove to be more positive than negative for Canadian farmers. 